\title{
Anna Podemska-Kałuża*
}

iD https://orcid.org/0000-0001-5179-0514

\section{The blogosphere as a medium for the professional stimulation of teachers Initial study}

\section{Polish teachers in the face of the expansion of new technologies}

The transformations of the modern world have been triggering major changes in education. The dynamic development of a knowledge society and pervasive information technologies ${ }^{1}$ have permanently re-organised the value structure of the processes of teaching and learning in the modern school, and have re-defined teacher attitudes. ${ }^{2}$ That has been mainly the result of the role which the global network plays in the lives of $21^{\text {st }}$ century humans. In the last two decades, the internet has become one of the basic media of communication, including for the education environment. ${ }^{3}$

New technologies haveincreasinginfluence on the work of Polish teachers. Operating within cyberspace enables teachers to increase their efficiency in conveying knowledge and communicating with pupils. ${ }^{4}$ The internet constitutes a medium

* Ph.D. in humanities, assistant professor, Adam Mickiewicz University in Poznań, Faculty of Polish and Classical Philology, Institute of Polish Philology, Department of Teaching Polish Literature and Language, ul. A. Fredry 10, 61-701 Poznań, podemska@amu.edu.pl

1 Internet - fenomen społeczeństwa informacyjnego, T. Zasępa (ed.), Częstochowa 2001.

2 M. Castells, Społeczeństwo sieci, trans. M. Marody, K. Pawluś, J. Stawiński, S. Szamański, Wydawnictwo Naukowe PWN, Warsaw 2007; M. Furmanek, "Społeczeństwo sieciowe - człowiek w sieci", in: Edukacja Medialna. Nowa generacja pytań i obszarów badawczych, M. Sokołowski (ed.), Oficyna Wydawnicza "Kastalia", Olsztyn 2004, pp. 265-273.

3 A. Ogonowska, "Internet jako przestrzeń i forma komunikacji.Cz. 1", Nowa Polszczyzna 2006, issue 3 , pp. 43-46.

4 The matter was discussed in more detail in M. Maziarz, "Rola mediów elektronicznych i edukacji medialnej w szkole.E-Twinning, Blogi i portale społecznościowe w komunikowaniu się 
through which Polish teachers engage in intensive activities of professional improvement, especially in that, "the internet is a dynamic place with multiple variants and solutions," as indicated by Don Tapscott. ${ }^{5}$

Contemporary Polish teachers are present in the virtual reality through:

- content posted on school websites,

- teacher forums and groups on the internet, ${ }^{6}$

- own websites,

- writing teacher blogs, ${ }^{7}$

- social media accounts (Facebook, Twitter, Instagram). ${ }^{8}$

The above summary of the areas of digital presence of Polish teachers proves the viability of Zdzisława Dacko-Pikiewicz and Marek Walancik's ascertainment: "Technological progress and cyberspace are the reasons why contemporary opportunities for using various forms of participation in community life continue to grow."' One's functioning in cyberspace enables them to present their own teaching achievements, and professional and personal growth. The basic forms of online presence consists today of texts posted on the internet, webinars, blogs, podcasts, visual content, photo galleries, etc., the task of which is to provide other internet users with the reliable news and information they require and which are associated with their related school teaching.

A considerable portion of material prepared and posted online by Polish teachers is intended for their fellow teachers. Such profiling of internet content triggers many questions in regards to specifying the nature and scope of the influence of digital content.

z uczniem i przekazywaniu wiedzy”, in: Komunikowanie (się) w mediach elektronicznych: język, edukacja, semiotyka, M. Filiciak, G. Ptaszek (eds.), Wydawnictwa Akademickie i Profesjonalne, Warsaw 2009, pp. 240-254. Another important text was: T. Huk, „Edukacyjna wartość blogów internetowych", Chowanna 2007, vol. 2, pp. 142-157.

5 Cyfrowa dorosłość: Jak pokolenie sieci zmienia nasz świat - Don ..., lubimyczytac.pl/ksiazka/.../ cyfrowa-doroslosc-jak-pokolenie-sieci-zmienia-nasz-swiat [accessed on 4.09.2017]. [Unless indicated otherwise, English versions of quotations were translated from Polish]

6 K. Motyl, "Internetowe forum nauczycieli - wyzwanie dla pedeutologii", Prace Naukowe Akademii im.Jana Długosza w Częstochowie, Pedagogika, Year 2014, vol. XXIII, pp. 219-229.

7 D. Janczak, "Nowe technologie - blog edukacyjny", Meritum 2008, issue 4, pp. 95-97.

8 E. Musiat, "Media społecznościowe - narzędzie cyfrowej szkoły", Nowa Szkoła 2013, issue 10, pp. 13-20; E. Pryłowska-Nowak, "Komunikacja poprzez media społecznościowe", Meritum 2014, issue 4, pp. 44-48; J. Okuniewska, "Facebook sposobem na...", Głos Nauczycielski 2014, issue 32/33, p. 19.

9 Z. Dacko-Pikiewicz, M. Walancik,"Wprowadzenie", in: Współczesne społeczeństwo w wirtualnej rzeczywistości: wielość szans i dylematów = Modern society in virtual reality: the multitude of opportunities and dilemmas, Z. Dacko-Pikiewicz, M. Walancik (eds.), Oficyna Wydawnicza „Impuls”, Krakow 2014. As quoted in: Współczesne społeczeństwo w wirtualnej rzeczywistości - wieloś..., https://www. impulsoficyna.com.pl/.../wspolczesne-spoleczenstwo-w-wirtual... [accessed on 29.07.2019]. 
The most common questions posed in teacher social networks include:

- Who inspires Polish teachers?

- How do you acquire teaching novelties and interesting teaching materials?

- Which locations on the internet do you use for professional development?

- What types of material do you gather? How would you evaluate its usefulness?

- Which websites do you frequent?

- Whose blogs do you read the most often?

- Which teaching texts on the internet are the most valuable? Why are they worth recommending?

The many answers included in comments underneath posts demonstrates that there is an increase in the significance of teaching blogs as the primary form of selfcreation and self-expression of Polish teachers. ${ }^{10}$ Their online posts give evidence that within the last decade the educational blogosphere, also referred to by teachers as "belferskablogosfera" [beak blogosphere], has become for Polish teachers an area of intensive professional activity. It consists of online journals by creative Polish teachers who share their teaching and education experiences with other Polish teachers, students of university teacher courses, and parents. Observations of the online presence of teachers who participated in the Szkoła z Klasą 2.0 programme indicated that:

\begin{abstract}
"the fact of maintaining a blog is for teachers an excellent opportunity to have their own educational spot on the internet, to organise it as they see fit, and fill it with content which benefits not only the pupils at their original school, but also pupils and teachers throughout Poland."'1
\end{abstract}

\title{
From the "blogging trend" to teacher specialised journals
}

The first teacher blogs appeared in cyberspace in the 2000s. ${ }^{12}$ The popularity and the rapid spread of the new form of communication in culture and education was a result of the "blogging trend," ${ }^{13}$ yet online journals became common only after

10 B. Przywara, "Współczesne formy autokreacji - blogi publicystyczne, serwisy społecznościowe, czaty", in: Nie tylko Internet. Nowe media, przyroda i „technologie społeczne” a praktyki kulturowe, J. Mucha (ed.), Zakład Wydawniczy „NOMOS”, Krakow 2010, pp. 119-129; A. Podemska-Kałuża, "Szkolny polonista w sieci: formy autoprezentacji i autopromocji zawodowej", in: Autopromocja, autoprezentacja, wizerunek w mediach audiowizualnych, vol 4, A. Kalisz, E. Tyc (eds.), Wydawnictwo UŚ, Katowice 2018, pp. 59-77.

11 Blogi nauczycieli - BLOG Szkoły z Klasa 2.o - Blogi CEO, https://blogiceo.nq.pl/szkola2zero/ blogi-nauczycieli/ [accessed on 30.08.2017].

12 New forms of teacher and pupil expression in the virtual world were discussed in M. Matuzik, "Blog - nowe narzędzie pracy nauczyciela i ucznia", Nowa Polszczyzna 2008, issue 1, pp. 33-35.

13 More findings regarding the cultural and education phenomenon were presented in A. Kozieł, "Modanabloga", Ergo. Forum Wychowawców 2005, issue 12, pp. 20-21. 
2010. 2012 was a major date in the development of the teacher blogosphere, as it was the year that many new teacher online journals were created. The increase in the number of teacher blogs was a result of the popularity of blog portals and mobile apps. ${ }^{14}$

Since the very beginning of the teacher blogosphere, BelferBlog by Dariusz Chętkowski, published on the website of the Polityka opinion weekly, has been very popular among Polish teachers. ${ }^{15}$ In the Ranking 10 blogów edukacyjnych [Ranking of 10 teaching blogs] the blog was presented as follows:

"BelferBlog is a blog by Dariusz Chętkowski, a teacher, writer, and a columnist. He teaches Polish, ethics and manages the philosophy club at the High School No. 21. He is also a lecturer at Wyższa Szkoła Pedagogiczna in Łódź. [...]

On his blog, he posts information regarding the Polish school system, state policy regarding schools, and what should be changed. The blog is not an alternative form for pupils, but it certainly is a source of a host of information for those interested in the school system or who wish to work in it."'16

Today, BelferBlog by Dariusz Chętkowski is one of the best-known Polish blogs devoted to education, which over the yearshas become an important voice of the community of Polish teachers with a considerable reach.

The Superbelfrzy RP portal, which also contains blog entries by teachers, is another noteworthy location on the internet often mentioned by Polish teacher internet users. ${ }^{17}$ Superbelfrzy RP is a "community of edu-changers", who thus describe themselves: "we engage in 'grass-roots' changing of the face of the boring education lagging behind the rapidly changing reality of education. / We are all passionate about teaching - our successes and the successes of our pupils are a proof of that."

The growing popularity of blogs devoted to education has resulted in the keen interest of educators and Polish teachers in this form of professional activity. ${ }^{19}$

14 Guidelines on how to create and maintain a blog: Nauczyciel w świecie TIK Cz. 1. Blog edukacyjny - jak go założyć i ..., www.pbwnowysacz.pl/edc_user_data/dat_files/cz1_blog_edukacyjny.pdf [accessed on 30.08.2017].

15 BelferBlog | Blog by Dariusz Chętkowski, https://chetkowski.blog.polityka.pl/ [accessed on 31.08.2017].

16 Ranking 10 blogów edukacyjnych - Socjomania, https://socjomania.pl/ranking-10-blogow-edukacyjnych [accessed on 31.08.2017].

17 According to the information posted on the Superbelfrzy home website: "This is an open community blog devoted to independent education-focussed writing." Blogi prowadzone przez Superbelfrów - Superbelfrzy RP, www.superbelfrzy.edu.pl/o-blogu/blogi-prowadzone-przezsuperbelfrow/ [accessed on 1.09.2017].

18 O blogu - Superbelfrzy RP, www.superbelfrzy.edu.pl/o-blogu/ [accessed on 1.09.2017].

19 B. Śliwerski, Ped@gog w blogosferze, Oficyna Wydawnicza "Impuls", Krakow 2008; D. Janczak, "Nowe technologie - blog edukacyjny", Meritum 2008, issue 4, pp. 95-97; J. Padewski, 
Initially, blogs were referred to as online journals, ${ }^{20}$ as they tended to highlight the personal lives of their authors ${ }^{21}$ rather than the facts of their professional activities. As the teacher blogosphere changed, authors abandoned the formula of the online journal, turning instead to the specialist blog form, having their specific themes that were considerably more founded on the notions significant to their line of work. ${ }^{22}$ Today, the blogs of Polish teachers rarely include any content regarding their private lives. The focus of internet recipients is now placed solely on the discussions of professional topics and issues. The education blog is for teachers a method of documentating their teaching and education work online.

When reading the blogs, internet users can find information on the following topics:

- modern tools of Polish teachers (methods, strategies, techniques);

- innovation in the teaching of Polish and school pedagogy;

- new technology in education;

- successful shaping of teacher-pupil relations (in particular: stimulating pupils to engage in class work, and maintaining discipline in-class);

- teaching aids, work charts, ideas for games and play, digital content;

- interesting education projects and education initiatives;

- news in science and education;

- information on supplementary courses for teachers, and other methods for expanding their professional competences. ${ }^{23}$

The popularity of education blogs has resulted in the growth of their virtual audiences: a constantly growing number of teachers and Polish students state that they seek information on teaching Polish online. That is a result of the expansion

"Blog w dydaktyce polonistycznej w gimnazjum: rekonesans", Forum Nauczycieli 2011, issue 3, pp. 21-22; T. Prokowska, "Blog jako narzędzie dydaktyczne w bibliotece szkolnej", Biblioteka w Szkole 2014, issue 7-8, supplement "Biblioteka - Centrum Informacji", pp. 13-15; M. Wiaderek, "Pomysły na blogi", Biblioteka w Szkole 2011, issue 5, supplement "Biblioteka - Centrum Informacji", issue 2, pp. 17-18.

20 M. Matuzik, "Pamiętnik zagubiony w sieci", Nowa Polszczyzna 2008, issue 4, pp. 44-47.

21 M. Olcoń, "Blog jako dokument osobisty - specyfika dziennika prowadzonego w Internecie", Kultura i Społeczeństwo 2003, issue 2, pp. 123-143.

22 M. Sokół, R. Sokół, Blog, więcej niż internetowy pamiętnik: przedstaw się światu, Wydawnictwo Helion, Gliwice 2008.

23 The summary of notions important for the technical content of the blogs of Polish teachers was prepared based on the analysis of the themes raised in blogs whose authors belong to the private Facebook group POLONIŚCI NA CZASIE. POLONIŚCI NA CZASIE Public Group | Facebook, https://www.facebook.com/groups/polskinaczasie/ [accessed on 20.07.2019]. Initially, the group was called Nauczyciele polskiego. Nauczyciele polskiego - Strona główna | Facebook, https://pl-pl.facebook.com/nauczycielepolskiego/ [accessed on 20.08.2017]. 
of modern technology and the "cabling" of the lives and technical world of modern humans. ${ }^{24}$ Teacher blogs are mostly focussed on communicating technical content, sharing teaching experiences, disseminating knowledge acquired at workshops, training sessions and courses, etc. As Anna Stoppel aptly noted "blogs are one of the best ways of communicating and building relations with people." ${ }^{25}$ That means that today online written content creates virtual bonds of various natures. ${ }^{26}$

\section{A new trend: teacher blogs in social media}

The increase in teachers' interest in blogs was triggered by social media. Thei rpresence on Facebook, Twitter or Instagram ${ }^{27}$ increased the popularity of blogs of Polish teachers. An extremely interesting set of study materials consists of the blogs of Polish female teachers who actively participate in the private Facebook group POLONIŚCI NA CZASIE (originally: Nauczyciele polskiego). ${ }^{28}$ The group has been present in social media since February 2016. It was established by Agata OkrojekZakrzewska, a blogger and one of the group's administrators.

Other valuable blogs which exist within that social media community include:

- Belferka w sieci by Magdalena Góra ${ }^{29}$

- Blue School by a blogger with the username Blue-Nika (in real life: Monika Czerkas) $)^{30}$

- Lekcje Polskiego by Karolina Starnawska, nee Jędrych ${ }^{31}$

- Polonistka przy tablicy by Asia Heftowicz ${ }^{32}$

24 More problem-focussed findings: Ch. Jonscher, Życie okablowane. Kim jesteśmy w epoce przekazu cyfrowego?, trans. L. Niedzielski, Wydawnictwo Muza SA, Warszawa 2001; M. Sikora, "Człowiek w teatrze życia sieciowego", in: Edukacja Medialna. Nowa generacja pytań i obszarów badawczych, M. Sokołowski (ed.), Oficyna Wydawnicza „Kastalia”, Olsztyn 2004, pp. 377-385.

25 A. Stoppel, "Nowe media w kampaniach wyborczych", Przeglad Naukowo-Metodyczny. Edukacja dla Bezpieczeństwa 2016, R. 9, issue 1, p. 207.

26 The issue was discussed in: U. Jarecka, "Wirtualne więzi w globalizujacym się świecie", in: Kultura w czasach globalizacji, M. Jacyno, A. Jawłowska, M. Kempny (eds.), IFiS PAN, Warsaw 2004, pp. 256-276.

27 A. Michniuk, "Aktywność internautów w mediach społecznościowych", Wychowawca 2016, issue 11, pp. 7-9.

28 POLONIŚCI NA CZASIE Public Group | Facebook, https://www.facebook.com/groups/polskinaczasie/ [accessed on 20.07.2019].

29 Belferka w sieci, belferkawsieci.blogspot.com/ [accessed on 13.09.2017].

30 Blue School, blue-school.blogspot.com/ [accessed on 12.09.2017].

31 Originally: LekcjePolskiego, www.lekcjepolskiego.com/ [accessed on 12.09.2017]. Currently, the blog is available at the following address: Lekcje Polskiego - Pisze Karolina Starnawska, lekcjepolskiego.pl/ [accessed on 18.07.2019].

32 polonistk@przytablicy, polonistkaprzytablicy.blogspot.com/ [accessed on 13.09.2017]. 
- Polski na czasie by Agata Zakrzewska-Okrojek ${ }^{33}$

- Takie tam po polsku by Joanna Waszkowska ${ }^{34}$

- Utkane z codziennych doświadczeń szkolnych by Wioletta Rafałowicz ${ }^{35}$

- Widziane oczami nauczyciela...: szkoła inaczej by Marlena Kowalska ${ }^{36}$

- Zakręcony Belfer by Asia Krzemińska. ${ }^{37}$

The listed blogs by Polish female teachers form an open, dynamically developing collection of online writings by Polish teachers. The list is not final, and the indicated titles should only be considered as representative examples of an extremely expansive group of digital writings. The bloggers also promote their blogs with the online writings on Facebook.$^{38}$ Such pages, or accounts, constitute a common tool for promoting education blogs, they promote the reading of the blogs, they contain material which can direct internet users' attention to those online writings (attractive leads, highlighted audio-visual content, and photographs being proof of non-conventional lesson activities). This observation was confirmed in a post by Joanna Waszkowska: "Here's the Facebook intro page for posts which I publish in my blog." ${ }^{39}$ Such a determination of the function of blog pages on Facebook proves the significance of the pages as a major part of self-presentation and self-promotion by Polish teachers. This is an outcome of the continuously growing importance of social media for the professionalisation of teacher work. ${ }^{40}$

33 BLOG | POLSKI NA CZASIE SZKOŁA JĘZYKA POLSKIEGO W ..., polskinaczasie.pl/blog/ [accessed on 12.09.2017].

34 Takie tam po polsku, uczycielnica.blogspot.com/ [accessed on 13.09.2017].

35 Utkane z codziennych doświadczeń szkolnych, https://skokiporozum.blogspot.com/ [accessed on 13.07.2019].

36 widziane oczami nauczyciela...: szkoła inaczej, https://szkolainaczej.blogspot.com/ [accessed on 12.07.2019].

37 zakręconybelfer, zakreconybelfer.blogspot.com/ [accessed on 12.09.2017]. Today, new posts are released at: Zakręcony belfer - Strona kreatywnego nauczyciela języka polskiego ..., https:// zakreconybelfer.pl/ [accessed on 24.07.2019].

38 For example: Belferka w sieci - Home |Facebook, https://d.facebook.com/belferkawsieci/ [accessed on 5.08.2019]. Lekcje Polskiego - Strona główna | Facebook, https://pl-pl.facebook.com > ... > Strona poświęcona edukacji [accessed on 5.08.2019]. Polonistka przy tablicy - Home | Facebook, https:// www.facebook.com > Pages > Businesses > Education [accessed on 5.08.2019]. Uczycielnica - Home | Facebook, https://www.facebook.com > Pages > Public Figure > Blogger [accessed on 5.08.2019] (page of Takie tam po polsku blog). Utkane z codziennych doświadczeń szkolnych - Home | Facebook, https://www.facebook.com > ... > Other > Brand > Website > Personal Blog [accessed on 5.08.2019]. Widziane oczami nauczyciela - Home | Facebook, https://www.facebook.com > ... > Brand > Website , Education Website [accessed on 5.08.2019]. Zakręcony belfer - Strona główna | Facebook, https:// pl-pl.facebook.com , ... , Strona poświęcona edukacji [accessed on 5.08.2019].

39 Uczycielnica-Home|Facebook, https://www.facebook.com/uczycielnica/ [accessed on 05.09.2017].

40 J. Okuniewska, "Facebook sposobem na...", Głos Nauczycielski 2014, issue 32/33, p. 19. Vide also: Człowiek w obliczu szans cyberprzestrzeni i świata wirtualnego, J. Bednarek (ed.), Difin, Warsaw 2014. 
An initial analysis of the blogs promoted on Facebook in the POLONIŚCI NA CZASIE group indicates that blogging is more popular among women than men. Among the rare male bloggers, the most noteworthy include: Kamil Kromski, the author of Jezykowe rozważania młodego polonisty, ${ }^{41}$ and Tomasz Filipowicz, who systematically posts invitations to read posts in the blog Klasyka Literatury i Fil$m u .^{42}$ The predominance of female authors of blogs is a result of the feminisation of the profession of Polish teaching at every level of education. ${ }^{43}$ The online Polish teacher education blogs are usually maintained by people aged $23-35$, though there are blogs by more experienced teachers with considerable school practice (e.g. Asia Heftowicz, the author of the polonistk@przytablicy ${ }^{44}$ blog). Male bloggers mainly include Polish schoolteachers, and blogs on teaching Polish are much less common among university teachers (one noteworthy example is the Lekcje Polskiego blog by Karolina Starnawska nee Jędrych ${ }^{45}$ ).

\section{Digital audience of teacher blogs}

The education-oriented blogosphere consists of themed posts which have become increasingly professional over the years. That is probably due to the fact that some bloggers aspire to gain the status of experts. ${ }^{46}$

Some of the posts are blogs dedicated for teachers' "personal" classes, intended for pupils and their parents. Karolina Jędrych thus explained the motivations behind teachers blogging for pupils:

41 Językowe rozważania młodego polonisty, filologpolski.blogspot.com/ [accessed on 14.01.2019].

42 Blog, www.klasykaliteraturyifilmu.pl/ [accessed on 14.09.2017].

43 The feminisation of Polish school education was discussed in more detail in: A. Gromkowska-Melosik, "Feminizacja zawodu nauczycielskiego - 'różowe kołnierzyki' i paradoksy rynku pracy", Studia Edukacyjne 2013, issue 25, pp. 85-100.

44 In the post: Witaj w moimświecie [Welcome to my world], digital recipients can learn the following details about the blogger: "I am a Polish teacher, for the past 15 years I have worked with wonderful young people in a small town in the centre of Poland." Vide: polonistk@przytablicy, polonistkaprzytablicy.blogspot.com/ [accessed on 13.09.2017].

45 The blogger is a Polish teacher at Zespół Ogólnokształcących Szkół Społecznych STO in Bytom and is an assistant professor at the Chair of Teaching Polish Language and Literature, University of Silesia. Karolina Jędrych thus wrote about herself: "Teacher, blogger, wanderer. I teach at Społeczna in Bytom, I am a lecturer at the University of Silesia. I enjoy reading." Karolina Jędrych - Google+, https://plus.google.com/103975141277783349343 [accessed on 13.09.2017]. Vide also: Zakręcony belfer - Strona kreatywnego nauczyciela języka polskiego ..., https://zakreconybelfer.pl/ [accessed on 24.07.2019].

46 M. Juza, "Wiedza ekspercka i mądrość zbiorowa w komunikacji internetowej", Studia Socjologiczne 2007, issue 3, pp. 37-58. 
I decided to blog about my lessons in November 2008, after two months of my schoolwork. I wanted to, first of all, have a record of my ideas for lessons, and, secondly, to remain in contact with pupils also after school. Initially, the "LekcjePolskiego" blog was intended exclusively for them, middle school pupils; it was our form of contact. I posted there topics for homework, and I responded to requests to postpone it. I enjoy writing a lot, I had already blogged before, so it was somewhat natural that I started blogging about lessons. ${ }^{47}$

Blogs by Polish teachers include educational material and information which anyone interested may use in teaching/learning ("tablet children" ${ }^{\text {"48 }}$ and digital teenagers), and in interpersonal contacts (teacher-parent). From such specified educational posts on the internet, pupils may acquire useful information, texts to be read for the following lesson, learning aids activated during a lesson, and links to recommended websites. Polish teachers can also utilise e-registers as a virtual notice board for pupils. It also helps them promote books worth reading, artistic films worth watching, and cultural events worth going to.

Such blogs are maintained in a very logical and clear manner (in terms of the arrangement of the content), with consideration of the receptive needs of young people. They constitute an interesting and efficient form of supporting teachers' activities. Pupils can also find in the posts additional tasks (both within the required teaching content and content which exceeds the curriculum), tests, exams and other forms of assessment in electronic form, and multimedia presentations and projects prepared by pupils. Sometimes blog posts enable teachers to continue lesson activities: these include proposals for committed pupils interested in educational work outside the school. The difference in the manner of conducting those educational activities stems from the fact that those are fulfilled online, and pupils participate in that form voluntarily, without any classroom pressure.

Polish teachers use blog posts as an education location within the virtual reality where "tablet children" and digital teenagers can post their homework tasks (usually essays, though other forms of expression have been identified as well). Thus, a blog becomes a space used for collecting homework and projects. The Takie tam po polsku blog is an example of merging the traditional array of teaching instruments with new trends in Polish education. Joanna Waszkowska, its author, thus defined the content of her online posts: "I describe here projects developed by the students of my classes. To be remembered. Sometimes I add a sentence or two

47 Lekcje na blogu - Silesion.pl, https://silesion.pl , Komentarz , Lekcje na blogu [accessed on 16.09.2017].

48 "Tablet children" as a new generation of pupils were discussed in the article: D. Romanowska, E. Lis, "Tabletowe dzieci", Newsweek 2015, issue 31, pp. 10-14. 
on teaching innovations." ${ }^{49}$ Magdalena Góra, another blogger and the creator of Belferka $w$ sieci, thus discussed her work with her pupils:

Teaching give me great pleasure, it is my passion, occupation and hobby. I am extremely privileged to be working with wonderful young people open to all my crazy ideas. I constantly seek out new inspirations, interesting work methods, and methods for utilising ICTs in my lessons. ${ }^{50}$

From the point of view of school psychology, a teacher blog, focussed on remaining in contact with pupils, offers a great opportunity for shy, introverted teenagers, who rarely become active during regular class work. Blogs by Polish teachers will help intensify work with computerised children, ${ }^{51}$ even more so considering the fact that contemporary education is increasingly recognising the needs of pupils "immersed in the web." 52

Apart from education blogs intended for pupils, there are also online journals whose main recipients include other Polish teachers. Those blogs exist in teacher groups, fora and websites. Blogging female Polish teachers often indicate in their own posts they can also be found in other locations in cyberspace. For example, on the homepage of polonistk@przytablicy, visitors will find the following captions: "My idea was featured on 'edukacja z pasją"; "a guest contributor of SUPERBELFRZY."53 Apart from textual messages which draw the attention of digital recipients to other online locations with fragments of an education blog, there also appear iconic marks (references to a recognisable logo in the area of education).

49 This piece of information, functioning as a motto, is placed on the blog's homepage: Takie tam po polsku, uczycielnica.blogspot.com/ [accessed on 13.09.2017].

50 More at: Belferka w sieci, belferkawsieci.blogspot.com/ [accessed on 13.09.2017].

51 Internet a psychologia: możliwości i zagrożenia, W. J. Paluchowski (ed.), trans. M. Ferenc-Michelson et al., Wydawnictwo Naukowe PWN, Warsaw 2009; M. Jędrzejko, D. Morańska, Cyfrowi tubylcy. Socjopedagogiczne aspekty nowych technologii cyfrowych, Oficyna Wydawnicza Aspra-JR, Dąbrowa Górnicza-Warsaw 2013; Media elektroniczne w życiu dziecka w kontekście wartości wychowawczych oraz zagrożeń, J. Izdebska (ed.), Wydawnictwo Uniwersyteckie Trans Humana, Białystok 2008.

52 For example, the notion was discussed in the following texts: Dzieci i młodzież w świecie technologii cyfrowej, E. Janicka-Olejnik, K. Klimek (eds.), Wydawnictwo Akademii Humanistyczno-Ekonomicznej, Łódź 2016; D. Janczak, "Media społecznościowe kluczem do młodzieży", Dyrektor Szkoły 2016, issue 6, pp. 52-55; D. Janczak, "Wykorzystanie tabletów na lekcji”, Dyrektor Szkoły 2015, issue 11, pp. 56-59, K. Paliwoda, "Nauczanie blogowaniem", Przegląd Edukacyjny 2009, issue 1, pp. 11-12; S. Polcyn-Matuszewska, "Facebook w edukacji”, Remedium 2015, issue 1 , pp. 22-23.

53 Both pieces of information appear on the blog's homepage, in a strip on the right-hand side: polonistk@przytablicy, polonistkaprzytablicy.blogspot.com/ [accessed on 13.09.2017]. 
A "teacher blog" is an online notebook, in which a digital teacher posts entries regarding the notions they are interested in in teaching Polish, pedagogy, and school psychology. The e-journals by female Polish teachers sometimes constitute virtual repositories of lessons ideas, archives of materials used, and teaching solutions tested during lessons. The teacher blogosphere constitutes a virtual treasure trove of knowledge easily available at arm's reach, or rather, in this case, a mouse click.

Online recipients, usually Polish teachers, seek interesting topics and ideas for "semi-crazy scenarios" on the internet. Such expectations can be satisfied at blogs such as Zakręcony Belfer by Asia Krzemińska, which the author defined in the following manner: "A blog of a creative teacher. About work, though not exclusively. Sometimes to be taken with a pinch of salt. With emphasis of the fact that education doesn't have to be boring." ${ }^{34}$ These creative non-schematic journals by female Polish teachers constitute one of the basic forms of teacher expression.

The process of writing a teacher journal for the digital audience is continuous and linear. Blogs intended for pupils feature posts published on a regular basis, at least a few times a month, as required based on school life. In e-journals, which are rather intended for adult recipients (other teachers, parents of pupils, interns and practising students), bloggers publish new posts every other week, sometimes every few weeks.

\section{Blogs as a tool for professional stimulation}

Posts published on education blogs may offer a catalyst for the activities of other Polish teachers, motivating them to intensify their teaching practice. Teachers who use teaching material from online journals stressed in their opinions that the content offers valuable inspiration. ${ }^{55}$ That is even more important considering the fact that when faced with the multitude of material available on the internet, contemporary teachers find it difficult to acquire, select and use professional information, which e-teachers can find in the virtual world. The ideas for creative Polish lessons which can be found in the teachers' blogosphere can be successfully applied in school education: blogs offer original ideas, usually tested in real life situations, which are available for immediate use during lessons. Therefore, they constitute extremely attractive content for Polish teachers seeking new teaching solutions. For example, the Utkane z codziennych doświadczeń szkolnych blog by Wioletta Rafałowicz includes a tab entitled Zbiór przydatnych materiałów [Set of

54 zakręcony belfer, zakreconybelfer.blogspot.com/ [accessed on 12.09.2017].

55 A comment dated 1 March 2017 to M. Góra's bio (in the O Autorce tab) included the following opinion: "I feel so inspired! :) I browsed some of the posts and immediately many ideas for new lessons started popping into my head. Wonderful blog, I will surely come back." As cited in: Belferka w sieci, belferkawsieci.blogspot.com/ [accessed on 13.09.2017]. 
useful material] offering numerous teaching aids (mainly within the field of new technology), which teachers can use during the "Polish hours." ${ }^{56}$ Magdalena Góra, the author of Belferka $w$ sieci, described how to work with a trimino generator: she explained in detail, "step by step" how to use the generator app for a simple education game in German. She translated the major findings, she discussed the results of using trimino in literature lessons, she indicated classical texts which enable work with the new tool (works by Adam Mickiewicz, Wesele by Stanisław Wyspiański). ${ }^{57}$ Karolina Jędrych (now Starnawska) discussed the literary inspirations which helped her create original creative lessons. The author of Lekcje Polskiego also mentioned the opportunity to access digital tools: "Under a separate tab, I collected the websites and blogs which I read and recommend." 58

Teachers active in social media establish intensive interpersonal and professional relationships. ${ }^{59}$ Proof of that is the nature of the relationship between the bloggers who form the Facebook group POLONIŚCI NA CZASIE (initially: Nauczyciele polskiego). The authors of online posts know each other, they often "visit each other", communicate with one another, conduct lively discussions in cyberspace and social media, and trigger the education dialogue in the community of digital Polish teachers. Karolina Jędrych (now Starnawska) thus explained the point of such relations:

The fact of being active on the internet enables me not only to better understand the world of middle schoolers, but, most of all, the world of teachers, people who eagerly share their ideas, who seek new solutions, and who wish to ensure more interesting, efficient and better teaching. We have not only our own blogs, but also Facebook groups, and we draw much inspiration from each other. ${ }^{60}$

56 Utkane z codziennych doświadczeń szkolnych: Zbiór przydatnych ..., https://www.pinterest.com/ pin/367324913345506254/ [accessed on 17.09.2017].

57 "Trimino is a variant of dominoes. In this case, we arrange triangles: each side must fit the side of another triangle. Through the game, you can revise almost any topic, practice spelling or grammar, match dates to events, protagonists to set books, etc. Of course, you can create the game 'by hand', but the trimino generator available on the website facilitates the matter greatly. Since it is in German, allow me to explain how it works." Układanka na polskim, czyli Trimino! | Belferka w sieci, belferkawsieci.blogspot.com/2017/10/ukadanka-z-polskim-czyli-trimino.ht... [accessed on 26.10.2017].

58 Blogowe inspiracje polonistyczne | Eduhoryzonty, www.eduhoryzonty.pl/blogowe-inspiracje-polonistyczne [accessed on 18.09.2017].

59 M. Szpunar, "Społeczności wirtualne - realne kontakty w wirtualnym świecie", in: Społeczeństwo informacyjne. Aspekty funkcjonalne i dysfunkcjonalne, L.H. Haber, M. Niezgoda (eds.), Wydawnictwo UJ, Krakow 2006, pp. 158-167.

60 Lekcje na blogu - Silesion.pl, https://silesion.pl > Komentarz > Lekcje na blogu [accessed on 16.09.2017]. 
The process of writing a blog and sharing their teaching experiences on the internet stimulates teacher cooperation. Bloggers exchange links to interesting teaching material, information regarding the possibilities of professional development and interesting self-development options (training schemes, conferences, workshops, education coaching), and links to information on participation in creative education projects. They publish films, animations, and multimedia presentations so that other teachers and authors of blogs can implement them quickly and efficiently during lessons. They carefully test the solutions proposed in other education blogs. That teacher cooperation in cyberspace was indicated in a post by Asia Heftowicz:

During the following lesson we began revising the names of cases, questions, and practising declensions.

Trimino proved useful. I borrowed the idea from the blogs of creative Polish teachers BLUE-SCHOOL and KREAKTYWNA NAUKI, and I adapted it to my needs. I found a manual version of trimino in the Zakręcony Belfer ${ }^{61}$ blog.

The blog by Marlena Kowalska also offers a description of how she was inspired by an online post by another Polish teacher.

\section{Description hidden in a box}

I had been planning the lesson for some time, and the post by Zakręcony Belfer reassured me that it was worth undertaking the task. ${ }^{62}$

Blogs help teachers establish new contacts with other teachers (provided that a blogger does not disable the option to comment on their posts). Teacher blogs are keenly followed by young Polish teachers, interns and contract teachers as they offer considerable technical support for beginning teachers. The initial years of a professional career are a time when people often seek answers to such questions as: how should I teach? what can I do better and more efficiently? how can I modify my lessons? Thanks to blogs, other Polish teachers can expand their array of technical tools. Blogs maintained by experienced Polish teachers offer many valuable teaching suggestions not only for teachers just starting on their career paths, but also for those who have been working for several years.

Blog posts by female Polish teachers have become an effective tool for creating a positive image of teachers. Their growing popularity indicates that the internet constitutes a medium of successful professional interaction. The presence of blogs

61 polonistk@przytablicy: Przypadki na okrągło, polonistkaprzytablicy.blogspot.com/2017/10/ przypadki-na-okrago.html [accessed on 21.10.2017].

62 widziane oczami nauczyciela...: szkoła inaczej, szkolainaczej.blogspot.com/ [accessed on 12.09.2017]. 
in virtual discourse enables teachers to establish new contacts, present and promote themselves, and open paths for cooperation which had been closed prior to the expansion of electronic media. ${ }^{63}$ The forms of presentation of professional activities on the internet amplify fact-based communication with other digital teachers. The culture of interaction and cooperation in cyberspace opens huge opportunities for professional stimulation and self-development, especially if they are efficiently used for the growth of Polish teachers and improving their professionalism.

\section{From immersion to new school future}

Teacher bloggers are the representatives of the generation "immersed in bits", which carries the slogan of the "end of the age of chalk" in Polish education. ${ }^{64}$ It is a generation which indicates, through the practical activities they undertake, what a huge and positive role new technology can play in modern school education. They share a conviction about the educational potential of digital tools: for those Polish teachers the title of the seminal book by Aleksandra Pezda isnot justa theoretical proposal for education, but a fact. Blogs as expressions functioning in the web have caused a revolutionary change in teacher communication; they are the manifestos of the "awakening school" and a turn in school education for the challenges of the $21^{\text {st }}$ century.

\section{Bibliography}

Castells Manuel, Społeczeństwo sieci, trans. Mirosława Marody, Kamila Pawluś, Janusz Stawiński, Sebastian Szymański, Wydawnictwo Naukowe PWN, Warsaw 2007.

Człowiek w obliczu szans cyberprzestrzeni i świata wirtualnego, Józef Bednarek (ed.), Difin, Warsaw 2014.

Dzieci i młodzież w świecie technologii cyfrowej, Ewa Janicka-Olejnik, Krzysztof Klimek (eds.), Wydawnictwo Akademii Humanistyczno-Ekonomicznej, Łódź 2016. Furmanek Marek, "Społeczeństwo sieciowe - człowiek w sieci”, in: Edukacja Medialna. Nowa generacja pytań i obszarów badawczych, Marek Sokołowski (ed.), Oficyna Wydawnicza “Kastalia”, Olsztyn 2004, pp. 265-273.

63 A. Heftowicz thus indicated how she was inspired by other teacher blogs in a post of 14 December 2017: "Five... type fries I came across the idea for grammar fries on the polskinaczasie blog, but I wouldn't be myself if I hadn't adapted it to my needs." Post available at: 2017 - polonistk@przytablicy, polonistkaprzytablicy.blogspot.com/2017/ [accessed on 19.07.2019].

64 A. Pezda, Koniec epoki kredy, Wydawnictwo Agora, Warsaw 2011. 
Gromkowska-Melosik Agnieszka, "Feminizacja zawodu nauczycielskiego - 'różowe kołnierzyki' i paradoksy rynku pracy”, Studia Edukacyjne 2013, issue 25, pp. 85-100.

Huk Tomasz, "Edukacyjna wartość blogów internetowych”, Chowanna 2007, R. 50, vol. 2, pp. 142-157.

Internet a psychologia: możliwości i zagrożenia, Władysław Jacek Paluchowski (ed.), trans. Małgorzata Ferenc-Michelson et al., Wydawnictwo Naukowe PWN, Warsaw 2009.

Internet - fenomen społeczeństwa informacyjnego, Tadeusz Zasępa (ed.), Częstochowa 2001.

Janczak Dorota, "Media społecznościowe kluczem do młodzieży”, Dyrektor Szkoły 2016, issue 6, pp. 52-55.

Janczak Dorota, "Nowe technologie - blog edukacyjny”, Meritum 2008, issue 4, pp. 95-97.

Janczak Dorota, "Wykorzystanie tabletów na lekcji”, Dyrektor Szkoły 2015, issue 11, pp. 56-59.

Jarecka Urszula, "Wirtualne więzi w globalizującym się świecie", in: Kultura w czasach globalizacji, Małgorzata Jacyno, Aldona Jawłowska, Marian Kempny (eds.), IFiS PAN, Warsaw 2004, pp. 256-276.

Jędrzejko Mariusz, Morańska Danuta, Cyfrowi tubylcy. Socjopedagogiczne aspekty nowych technologii cyfrowych, Oficyna Wydawnicza Aspra-JR, Dąbrowa Górnicza-Warsaw 2013.

Jonscher Charles, Życie okablowane. Kim jesteśmy w epoce przekazu cyfrowego?, trans. Lech Niedzielski, Wydawnictwo Muza SA, Warsaw 2001.

Juza Marta, "Wiedza ekspercka i mądrość zbiorowa w komunikacji internetowej", Studia Socjologiczne 2007, issue 3, pp. 37-58.

Kozieł Agata, “Moda na bloga”, Ergo. Forum Wychowawców 2005, issue 12, pp. 20-21.

Majgier Katarzyna, "Internet jako przestrzeń komunikacyjna”, Przegląd Psychologiczny 2000, vol. 43, issue 2, pp. 157-172.

Matuzik Marcin, "Blog - nowe narzędzie pracy nauczyciela i ucznia”, Nowa Polszczyzna 2008, issue 1, pp. 33-35.

Matuzik Marcin, "Pamiętnik zagubiony w sieci”, Nowa Polszczyzna 2008, issue 4, pp. 44-47.

Maziarz Magdalena, "Rola mediów elektronicznych i edukacji medialnej w szkole. E-Twinning, Blogi i portale społecznościowe w komunikowaniu się z uczniem i przekazywaniu wiedzy", in: Komunikowanie (sie) w mediach elektronicznych: język, edukacja, semiotyka, Mirosław Filiciak, Grzegorz Ptaszek (eds.), Wydawnictwo Akademickie i Profesjonalne, Warsaw 2009, pp. 240-254.

Media elektroniczne $w$ życiu dziecka $w$ kontekście wartości wychowawczych oraz zagrożeń, Jadwiga Izdebska (ed.), Wydawnictwo Uniwersyteckie Trans Humana, Białystok 2008.

Michniuk Anna, “Aktywność internautów w mediach społecznościowych”, Wychowawca 2016, issue 11, pp. 7-9. 
Motyl Karol, "Internetowe forum nauczycieli - wyzwanie dla pedeutologii", Prace Naukowe Akademii im. Jana Długosza w Częstochowie, Pedagogika, Year 2014, vol. XXIII, pp. 219-229.

Musiał Emilia, "Media społecznościowe - narzędzie cyfrowej szkoły", Nowa Szkoła 2013, issue 10, pp. 13-20.

Ogonowska Agnieszka, "Internet jako przestrzeń i forma komunikacji. Cz. 1", Nowa Polszczyzna 2006, issue 3, pp. 43-46.

Okuniewska Jolanta, “Facebook sposobem na...", Głos Nauczycielski 2014, issue 32/33, p. 19.

Olcoń Marta, "Blog jako dokument osobisty - specyfika dziennika prowadzonego w Internecie”, Kultura i Społeczeństwo 2003, issue 2, pp. 123-143.

Padewski Jakub, "Blog w dydaktyce polonistycznej w gimnazjum: rekonesans", Forum Nauczycieli 2011, issue 3, pp. 21-22.

Paliwoda Katarzyna, "Nauczanie blogowaniem”, Przegląd Edukacyjny 2009, issue 1, pp. 11-12.

Pezda Aleksandra, Koniec epoki kredy, Wydawnictwo Agora, Warsaw 2011.

Podemska-Kałuża Anna, "Szkolny polonista w sieci: formy autoprezentacji i autopromocji zawodowej", in: Autopromocja, autoprezentacja, wizerunek w mediach audiowizualnych. Vol. 4, A. Kalisz, E. Tyc (eds.), Wydawnictwo UŚ, Katowice 2018, pp. 59-77.

Polcyn-Matuszewska Sylwia, "Facebook w edukacji", Remedium 2015, issue 1, pp. 22-23.

Prokowska Teresa, "Blog jako narzędzie dydaktyczne w bibliotece szkolnej”, Biblioteka $w$ Szkole 2014, issue 7-8, supplement "Biblioteka - Centrum Informacji", pp. 13-15.

Pryłowska-Nowak Elżbieta, "Komunikacja poprzez media społecznościowe”, Meritum 2014, issue 4, pp. 44-48.

Przywara Barbara,"Współczesne formy autokreacji - blogi publicystyczne, serwisy społecznościowe, czaty", in: Nie tylko Internet. Nowe media, przyroda i "technologie społeczne" a praktyki kulturowe, Janusz Mucha, Zakład Wydawniczy "NOMOS", Krakow 2010, pp. 119-129.

Romanowska Dorota, Lis Ewelina, "Tabletowe dzieci", Newsweek 2015, issue 31, pp. 10-14.

Sikora Marcin, "Człowiek w teatrze życia sieciowego", in: Edukacja Medialna. Nowa generacja pytań i obszarów badawczych, Marek Sokołowski (ed.), Oficyna Wydawnicza "Kastalia", Olsztyn 2004, pp. 377-385.

Sokół Maria, Sokół Radosław, Blog, więcej niż internetowy pamiętnik: przedstaw się światu, Wydawnictwo Helion, Gliwice 2008.

Stoppel Anna, "Nowe media w kampaniach wyborczych", Przeglad Naukowo-Metodyczny. Edukacja dla Bezpieczeństwa 2016, R. 9, issue 1, p. 205-217.

Szlagor Piotr, "Potencjał smartfonów i tabletów w nauczaniu przedmiotowym", Meritum 2013, issue 4, pp. 75-77. 
Szpunar Magdalena, "Społeczności wirtualne - realne kontakty w wirtualnym świecie", in: Społeczeństwo informacyjne. Aspekty funkcjonalne i dysfunkcjonalne, Lesław H. Haber, Marian Niezgoda (eds.), Wydawnictwo UJ, Krakow 2006, pp. 158-167.

Śliwerski Bogusław, Ped@gog w blogosferze, Oficyna Wydawnicza “Impuls”, Krakow 2008.

Tapscott Don, Cyfrowa dorosłość: jak pokolenie sieci zmienia nasz świat, trans. Piotr Cypryański, Wydawnictwa Akademickie i Profesjonalne, Warsaw 2010.

Trojnar Mariusz, "Blog jako przestrzeń wymiany informacji”, Edukacja 2010, issue 2, pp. 104-111.

Wiaderek Marian, "Pomysły na blogi”, Biblioteka $w$ Szkole 2011, issue 5, supplement "Biblioteka - Centrum Informacji", issue 2, pp. 17-18.

Współczesne społeczeństwo $w$ wirtualnej rzeczywistości: wielość szans i dylematów = Modern society in virtualreality: the multitude of opportunities and dilemmas, Zdzisław Dacko-Pikiewicz, Marek Walancik (eds.), Oficyna Wydawnicza "Impuls", Krakow 2014.

Zając Jan M., “Zapośredniczone kontakty społeczne w sytuacjach zawodowych”, in: Re: Internet - społeczne aspekty medium. Polskie konteksty i interpretacje, Łukasz Jonak, Paweł Mazurek, Marta Olcoń, Anna Przybylska, Alek Tarkowski, Jan M. Zając (eds.), Wydawnictwa Akademickie i Profesjonalne, Warsaw 2006, pp. 153-175.

Zioło-Pużuk Karolina, "Media społecznościowe", Dyrektor Szkoły 2014, issue 4, pp. 50-53.

\section{Internet resources}

BelferBlog | Blog by Dariusz Chętkowski, https://chetkowski.blog.polityka.pl/ [accessed on 31.08.2017].

Belferka $w$ sieci, belferkawsieci.blogspot.com/ [accessed on 13.09.2017].

Belferka w sieci - Home |Facebook, https://d.facebook.com/belferkawsieci/ [accessed on 5.08.2019].

Blog, www.klasykaliteraturyifilmu.pl/ [accessed on 14.09.2017].

BLOG | POLSKI NA CZASIE SZKOEA JEZZYKA POLSKIEGO W ..., polskinaczasie. $\mathrm{pl} / \mathrm{blog} /$ [accessed on 12.07.2019].

Blogi nauczycieli » BLOG Szkoły z Klasa 2.0 - Blogi CEO, https://blogiceo.nq.pl/szkola2zero/blogi-nauczycieli/ [accessed on 30.08.2017].

Blogi prowadzone przez Superbelfrów - Superbelfrzy RP, www.superbelfrzy.edu.pl/o-blogu/blogi-prowadzone-przez-superbelfrow/ [accessed on 1.09.2017].

Blogowe inspiracje polonistyczne | Eduhoryzonty, www.eduhoryzonty.pl/blogoweinspiracje-polonistyczne [accessed on 18.09.2017].

Blue School, blue-school.blogspot.com/ [accessed on 12.09.2017].

Cyfrowa dorosłość: Jak pokolenie sieci zmienia nasz świat - Don ..., lubimyczytac.pl/ ksiazka/.../cyfrowa-doroslosc-jak-pokolenie-sieci-zmienia-nasz-swiat [accessed on 4.09.2017]. 
Edukacja z pasją - Blog dla ludzi, którzy do edukacji podchodza z ..., www.edukacjazpasja.pl [accessed on 28.08.2017].

Językowe rozważania młodego polonisty, filologpolski.blogspot.com/ [accessed on 14.01.2019].

Karolina Jędrych - Google+, https://plus.google.com/103975141277783349343 [accessed on 13.09.2017].

Koniec epoki kredy - Aleksandra Pezda - Ksiażka - Księgarnia ..., https://bonito. pl/k-90168062-koniec-epoki-kredy [accessed on 28.08.2017].

Lekcje na blogu - Silesion.pl, https://silesion.pl > Komentarz > Lekcje na blogu [accessed on 16.09.2017].

LekcjePolskiego, www.lekcjepolskiego.com/ [accessed on 12.09.2017].

Lekcje Polskiego - Pisze Karolina Starnawska, lekcjepolskiego.pl/ [accessed on 18.07.2019].

Lekcje Polskiego - Strona główna | Facebook, https://pl-pl.facebook.com > ... > Strona poświęcona edukacji [accessed on 5.08.2019].

Lubimy uczyć! taKઐMamy, lubimyuczyc.blogspot.com/ [accessed on 15.09.2017].

Nauczyciel wświecie TIK Cz.1. Blog edukacyjny - jak go założyći ..., www.pbwnowysacz. pl/edc_user_data/dat_files/czl_blog_edukacyjny.pdf [accessed on 30.08.2017].

Nauczyciele polskiego - Strona główna | Facebook, https://pl-pl.facebook.com/nauczycielepolskiego/ [accessed on 20.08.2017].

O blogu - Superbelfrzy RP, www.superbelfrzy.edu.pl/o-blogu/ [accessed on 1.09.2017]. 2017 - polonistk@przytablicy, polonistkaprzytablicy.blogspot.com/2017/ [accessed on 19.07.2019].

polonistk@przytablicy, polonistkaprzytablicy.blogspot.com/ [accessed on 13.09.2017]. polonistk@przytablicy: Przypadki na okragło, polonistkaprzytablicy.blogspot. com/2017/10/przypadki-na-okrago.html [accessed on 21.10.2017].

Polonistka przy tablicy - Home | Facebook, https://www.facebook.com > Pages > Businesses > Education [accessed on 5.08.2019].

POLONIŚCI NA CZASIE Public Group | Facebook, https://www.facebook.com/ groups/polskinaczasie/ [accessed on 20.07.2019].

Ranking 10 blogówedukacyjnych - Socjomania, https://socjomania.pl/ranking-10-blogow-edukacyjnych [accessed on 31.08.2017].

Takie tam po polsku, uczycielnica.blogspot.com/ [accessed on 13.09.2017].

Uczycielnica - Home |Facebook, https://www.facebook.com/uczycielnica/ [accessed on 5.09.2017].

Uczycielnica - Home | Facebook, https://www.facebook.com > Pages > Public Figure > Blogger [accessed on 5.08.2019]

Układanka na polskim, czyli Trimino! | Belferka $w$ sieci, belferkawsieci.blogspot. com/2017/10/ukadanka-z-polskim-czyli-trimino.ht... [accessed on 26.10.2017].

Utkane $z$ codziennych doświadczeń szkolnych, https://skokiporozum.blogspot.com/ [accessed on 13.07.2019]. 
Utkane z codziennych doświadczeń szkolnych - Home|Facebook, https://www.facebook.com > ... > Other > Brand > Website > Personal Blog [accessed on 5.08.2019]. Utkane z codziennych doświadczeń szkolnych: Zbiór przydatnych ..., https://www.pinterest.com/pin/367324913345506254/ [accessed on 17.09.2017].

widziane oczami nauczyciela...: szkoła inaczej, szkolainaczej.blogspot.com/ [accessed on 12.09.2017].

widziane oczami nauczyciela...: szkoła inaczej, https://szkolainaczej.blogspot.com/ [accessed on 12.07.2019].

Widziane oczami nauczyciela - Home | Facebook, https://www.facebook.com > ... > Brand > Website > Education Website [accessed on 5.08.2019].

Wspótczesne społeczeństwo w wirtualnej rzeczywistości - wielość ..., https://www.impulsoficyna.com.pl/.../wspolczesne-spoleczenstwo-w-wirtual... [accessed on 29.07.2019]. zakręcony belfer, zakreconybelfer.blogspot.com/ [accessed on 12.09.2017].

Zakręcony belfer - Strona główna | Facebook, https://pl-pl.facebook.com > ... > Strona poświęcona edukacji [accessed on 5.08.2019].

Zakręcony belfer - Strona kreatywnego nauczyciela języka polskiego ..., https://zakreconybelfer.pl/ [accessed on 24.07.2019].

Anna Podemska-Kałuża

\title{
Blogosfera jako medium aktywizacji zawodowej nauczycieli. Rekonesans
}

\author{
Streszczenie
}

Dynamiczny rozwój społeczeństwa informacyjnego i wszechobecność technologii informacyjnych zmieniły warsztat nauczyciela języka polskiego. Z powodu ekspansji form cyfrowych szkolni poloniści podejmują bardzo różne działania zawodowe w cyberprzestrzeni. Autorka zwraca uwagę na intensywną aktywizację nauczycieli języka polskiego w Internecie i omawia fenomen blogów nauczycielskich. Niezwykle interesującym zagadnieniem jest oddziaływanie blogów na szkolną dydaktykę języka polskiego i rozwój kompetencji zawodowych nauczycieli. Wydaje się, że pisanie dzienników w sieci może przynieść korzyści w cyfrowej szkole (dostosowanie procesów nauczania do potrzeb tabletowych dzieci i globalnych nastolatków, połączenie metod typowych dla rewolucji technologicznej z tradycyjnymi narzędziami dydaktycznymi). Przegląd blogów funkcjonujących na Facebooku umożliwił pokazanie różnych strategii pracy z uczniami i ewolucji postaw twórczych nauczycieli języka polskiego. 
Słowa kluczowe: nauczyciel, edukacja polonistyczna, aktywność w sieci, blogi edukacyjne, informacja, cyberprzestrzeń, portale społecznościowe, Facebook

\title{
The blogosphere as a medium for professional stimulation of teachers. Initial study
}

\author{
Summary
}

The dynamic development of the information society and the omnipresence of ICTs has changed the work of Polish teachers. As a result of the expansion of digital forms, Polish teachers engage in various professional activities in cyberspace. The author indicated that Polish teachers have become extremely active on the internet, and she discussed the phenomenon of teacher blogs. A hugely interesting issue is the influence of blogs on teaching Polish in schools, and the development of teachers' professional competences. The act of writing journals online may bring benefits for the digital school (by adapting teaching processes to the needs of tablet children and global teenagers, combining the methods typical for the technological revolution with traditional teaching tools). A review of blogs maintained on Facebook enabled the author to indicate various strategies of working with pupils, and the evolution of creative attitudes of Polish teachers.

Keywords: teacher, Polish philological education, activity in the web, education blogs, information, cyberspace, social media, Facebook

Anna Podemska-Kałuża, Ph.D. in humanities, assistant professor at the Department of Teaching Polish Literature and Language, Adam Mickiewicz University in Poznań, author of publications on multicultural education, the poetics of reception of various culture texts in the contemporary school system, and the individualisation of teaching pupils with special education needs. Her research focus also covers the notion of multi-sensoricity in literature, culture and education, and the modern forms of communication, particularly in the virtual space. Together with Aneta Grodecka, she wrote the book: Wielozmystowość. Filozofia i dydaktyka (2012). 